\title{
ETHNOGRAPHY IN A SHELL GAME: Turtles All the Way Down in Abidjan
}

\author{
SASHA NEWELL \\ Université Libre de Bruxelles \\ (iD) https: / / orcid.org/0000-0003-3517-8629
}

.. . the seemingly straightforward contrast between clarity and opacity is complicated in regimes of truth that, like the ones found in Inhumbane, encourage ambiguation over clarification, and dissimulation over revelation and confrontation. In other words, in regimes of truth that privilege openendedness.

- Julie Soleil Archambault

Dissimulation, deception, postponed dates, false pretexts, and the like are efficient ways of navigating and prolonging relationships.

—Françoise Berthomé, Julien Bonhomme, and Grégory Delaplace

We are currently living in an era when the North Atlantic faith in the value of transparency and sincerity (Keane 2002) faces severe challenges, as accusations of fake news undermine traditional voices of authority, as the distinction between legitimate news agencies and internet gossip becomes increasingly blurry, and as the workings of power and wealth within the invisible infrastructures of digital communication cause the Habermasian figure of democratic public transparency (see Habermas 1991) to teeter on a tightrope between tragedy and farce. As they

CULTURAL ANTHROPOLOGY, Vol. 34, Issue 3, pp. 299-327, ISSN 0886-7356, online ISSN 1548-1360. (C) American Anthropological Association 2019. Cultural Anthropology journal content published since 2014 is freely available to download, save, reproduce, and transmit for noncommercial, scholarly, and educational purposes. Reproduction and transmission of journal content for the above purposes should credit the author and original source. Use, reproduction, or distribution of journal content for commercial purposes requires additional permissions from the American Anthropological Association; please contactpermissions@americananthro.org.DOI:10.14506/ca34.3.01 
say in Kinshasa: "One can never know what goes on in the heart of another person" (Pype 2015, 117). But the consequences of living with/in a sociality of deception is that truth regresses infinitely, each narrative nested within a frame configured in turn by its own contextual frame, like the endless chain of turtles on which the world is said to be resting in a story whose etymology echoes its own punch line (Geertz 1973, 28). ${ }^{1}$ When deceit is deviant, it can be narrated out of the sphere of morality. When it is understood to constitute part of the tissue of sociality, the ability of both actors and ethnographers to define what happened is obscured, and all must struggle to patch their leaky narratives into persuasion. Rather than helplessly decry our inability to produce transparency in our public sphere or objective empiricism in our research, we need to work to take account of everyday dissimulation as a social modality, and trace the intersecting and open-ended worlds it produces in shared collective spaces, without ignoring the anxieties and paranoias that navigating such uncertain spaces requires.

So, what does it mean to perform ethnography from within a narrative frame of deceit, in which not only the ethnographer is a target of dissimulative acts but his interlocutors themselves may not have control over all the narrative frames? While "many anthropologists assume that empathy is an important part of what constitutes social relationships" (Robbins and Rumsey 2008, 415-16), my own ethnographic empathy came to involve awareness of active deception as a part of everyday sociality, which in practice requires a constant questioning of one's most intimate sphere. Opacity is not just a means of "cutting" relationships, as Niklas Hultin $(2013,42)$ depicts Strathernian information theory in his fascinating depiction of Ghanaian law, but can also be a form of relatedness in itself. For in Mount Hagen, "concealment is taken as a condition for growth" (Strathern 2000, 311). When social life resembles a shell game, it is imperative to move beyond a structure that places clarity and opacity as morally opposed valences aligned respectively with the creation and destruction of social relations, and rather come to terms with deception as a mode of sociality, even if, as Houltin also points out, this kind of relationality is inherently asymmetrical. Julie Soleil Archambault $(2017,15)$ describes a state of "epistemological uncertainty tied to pervasive suspicion; one that begs endless questions: Is this person trying to cause me harm, and is he or she aware that I am trying to harm them?" This closely resembles the feeling of social interaction in Abidjan.

My story also concerns ethnographic uncertainty, as I climbed from one interpretative frame to another and tried to avoid losing my money as well my fragile illusion of transcendent ethnographic understanding. In short, while I had come 
to Abidjan in 2015 interested in new relationships between politics and religion, I found myself right in the middle of an ongoing con on my first day back in Côte d'Ivoire. When my ethnography intersected with my friend's forgery enterprise, I began to worry that the entire thing was a ruse designed to get me to cough up bigger sums of money, a suspicion I was never able to resolve. In telling this story, I hope to chronicle not ethnographic failure but rather a kind of meta-ethnography of participant observation in a world in which everyone (including the anthropologist) runs the risk of falling prey to misleading narrative frames, where every social actor was likely to share my experience of epistemic murk. As these layers accumulate and crosscut in daily interactions, certainty is unlikely to emerge in any definitive sense for anyone involved. Rather than seeking the objective truth of what happened, I attempt here to track the way actors navigate and sometimes profit from endemic uncertainty, without ever resolving it. Furthermore, at a larger level, an ethnography of sociality under false pretenses provides us with the basis for thinking of culture more as a field of contesting persuasions than one of de facto shared cosmology and values.

\section{DECEPTION, IVOIRIAN STYLE}

Following Erving Goffman, we might accept that deception constitutes a social inevitability. I would nevertheless like to insist on the variability of how deception is perceived and evaluated - there are styles, habits, and ideologies of deception. To be clear, I am not arguing that Ivoirians are more deceptive than other people nor that the segment of criminality I found myself within represents all Ivoirians. But, following Daniel Jordan Smith's (2008) observations of Nigeria, I want to acknowledge an anxiety about deception that Ivoirians themselves speak about regularly, without making it out to be an inherent quality or the fault of the actors themselves. I think deception is a local semiotic ideology (Keane 2007, 16-17) — it forms part of what Abidjanais expect from communication, whether or not it objectively takes place there with more frequency than in other places.

Whatever these performative tendencies may have been in this region previously, they were undoubtedly exacerbated in Abidjan by the structural insecurity resulting from the economic crisis of the eighties, compounded by the disastrous structural adjustment policies of the nineties (Comaroff and Comaroff 2001; Roitman 2004; Guyer 2009), and ultimately followed by ten years of political instability when the country was divided between two presidents, each with armies and each claiming their opponent to be an imposter (McGovern 2011; Cutolo and 
Banégas 2012). Julien Bonhomme (2012, 226) writes of contemporary West and Central Africa:

This condition of insecurity brings about a climate of generalized suspicion, which is a hotbed for witchcraft accusations and violence, since no one trusts anyone anymore. Occult rumors take this collapse of trust to its extreme. "Everybody grows suspicious of everybody else," explains a Gabonese man commenting on penis snatching. "We don't know who is who anymore," adds another man.

I would like to bring this kind of social anxiety into juxtaposition with the Melanesianist perspective on the opacity of minds (Robbins and Rumsey 2008). Many anthropologists working in the region have found (to their frustration) that their interlocutors insist that other people's minds are inherently opaque and that their contents cannot (or should not) be imagined. If in Melanesia it is either impossible or improper to penetrate the opacity of others' minds, in Abidjan, the ability to do so is highly prized, because it is a basic assumption of social life that other people are actively deceiving their interlocutors, and that it is impossible to be certain of even the most intimate relationships.

In the 1990s, many Abidjanais youth who had entered the educational system expecting to exit with a well-paying job like the generation of the "Ivoirian Miracle" before them found themselves with no work except menial labor-something they associated with recent migrants from villages and neighboring countries. Many became chercheurs (searchers) looking for ways to make money informally rather than accept a low-pay, low-prestige menial job. At least this held true for men: most women readily accepted low-prestige work. This situation produced an intensive street culture of scamming, in which a kind of "honor among thieves" protected residents within certain moral boundaries of the community, while strangers remained appropriate targets of crime-though who actually counted as an insider was always a matter of interpretation and negotiation (Newell 2006). Under these circumstances, Abidjanais popular culture placed a high value on deceptive performances, as well as on the ability to see through them.

Perhaps because it was valued as an index of productivity, young men displayed their skill at deception by bluffing, acting wealthy and successful through the consumption of brand-name clothes, brandishing quantities of cash, imbibing copious quantities of alcohol, and demonstrating worldly knowledge and urban savvy (Newell 2012). Yet these displays very rarely actually deceived the audience. 
Bluffeurs were skilled performers, but their lack of wealth was public knowledge, especially within one's own quartier (quarter), where those spending as though there were no tomorrow were quite likely to be asking friends and family for money to eat when tomorrow arrived. Bluffing often occurred as an act of courtship and seduction, and men pretended that they were deceiving the women for which they performed. Women pretended to believe their own lovers, but revealed complete awareness of male economy in the abstract, while using their wiles to convince multiple men into contributing to their own economy (Newell 2009; Archambault 2017, 127-33). In this sense, the most intimate relationships were run through with the art of the con, even when bound by genuine affect. Yet the bluffeur wished to deceive only from a superficial perspective-pragmatically it was about showing off performative skill and about living, if only temporarily, within the frame produced through illusions. Mike McGovern (2011, 124) describes such conduct among Ivoirian youth as falling within Bateson's frame of play: "These actions in which we now engage do not denote what those actions for which they stand would denote." In this sense, the art of the bluff also reveals a positive social appreciation of mimesis as craft.

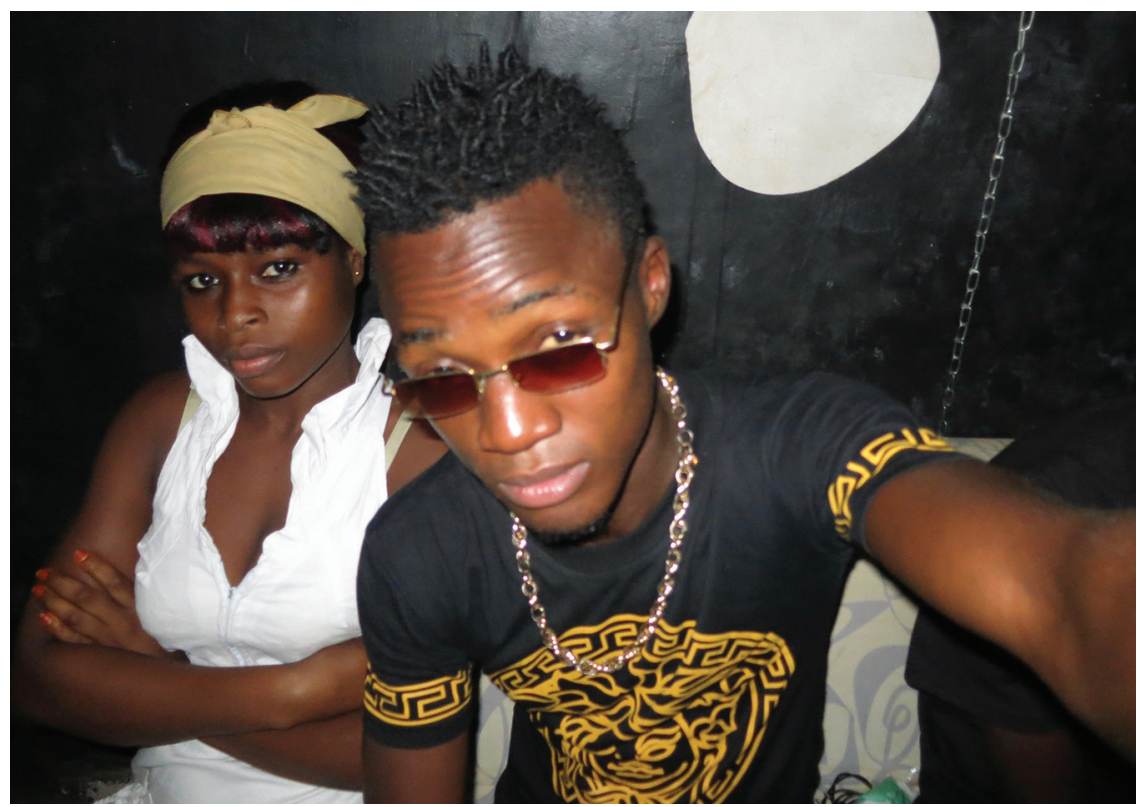

Figure 1. A bluffeur uses my camera to take a selfie with a young woman working in the maquis. Photo by Sasha Newell.

The possibility of deceit worked at various levels. For example, some residents paint messages on their homes clarifying that these were not for sale: false 
real estate agents had been selling people's houses out from under them. Everyday transactions, from getting change at a restaurant to riding the bus, became filled with suspicion and attempts to outwit others. Friends were likely to occasionally exploit faithful trust in one another, especially in cases of asymmetrical wealth. The saying went that "in Abidjan it is dangerous to have too many friends" (Newell 2006, 196). By 2010, the dream of most (especially male) youth was to become a brouteur, working in internet cafés with false profiles on social media to seduce wealthy, typically white, people from other countries and dupe them into sending money after the relationship was well established. Millions of dollars entered the country this way, so that Côte d'Ivoire is developing an international reputation for fraud on par with that of Nigeria.

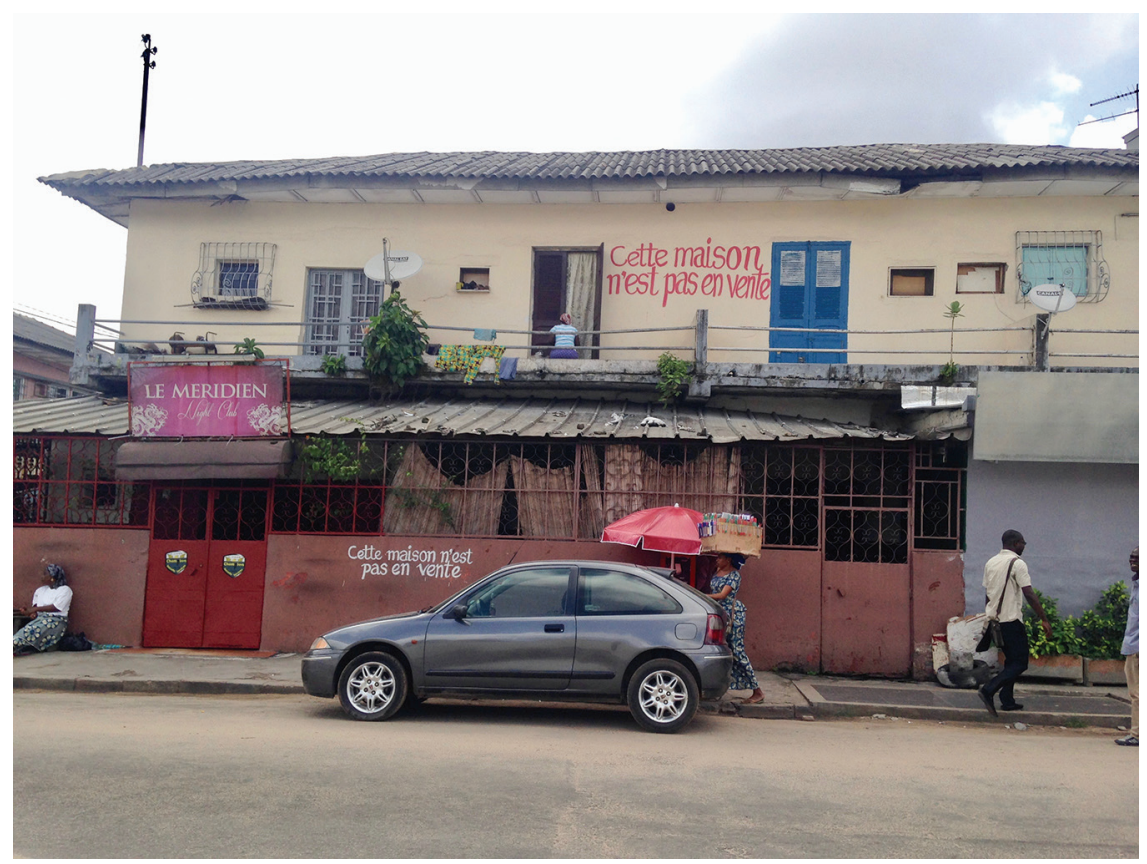

Figure 2. The ubiquity of scams made it necessary to make it clear to potential victims that the property in the photo was not for sale by painting the message "this house is not for sale" repeatedly on the wall. Photo by Sasha Newell.

The embedded pattern of deception in everyday life in Abidjan is alluded to by the oft-repeated proverb c'est "non" qui envoie palabre (it is no that causes fights). Championing a form of the white lie, the phrase indicates that one should always say yes when asked or invited to do something, whether or not one intends to follow through. The effect of this ethos was such that if I were to receive a call an hour or so after a rendezvous was supposed to take place to ask whether I would 
still show up, I was coached that the appropriate response would be something like "yes, I'm still coming, I'm just caught in traffic," even though I had no intention of arriving. I learned that to say no, even when one had a prior engagement, was likely to make the other person "hot," with risky, potentially even occult results. And since everybody seemed to know that yes did not really promise anything, the consequences of breaking one's word were unlikely to be serious, as long as one had some kind of mitigating excuse. The point was to allow everybody to save face, and never publicly reveal that one was prioritizing one set of people and plans over others. ${ }^{2}$

I will now turn to the story of my summer of 2015, when I returned to Abidjan after many years' absence, and fell headlong into a confidence scheme gone awry, or perhaps according to plan, depending on who does the telling. The telling of the story is the crux of the matter, because the confidence game is itself structured as a narrative, one with roles characterized by dramatic tension and a sequence of events leading to a climax and denouement. David M. Maurer (1940, 108) wrote that "confidence games are in reality only carefully rehearsed plays in which every member of the cast except the mark knows his part perfectly." Yet I would insist that unlike in conventional theater, in cons no one involved can be certain of the outcome, precisely because some of the actors remain unaware of the script. This uncertainty becomes multiplied when the layers of deception begin to overlap and some of the con men are actually marks as well. Since confidence schemes almost always rely on the mark participating in some kind of racket from which they think they will profit, many cons involve such layered deceptions, ${ }^{3}$ and therefore no one involved in a con can be certain they hold the entire script. Furthermore, the narrative structures involved in these layered deceptions have a kind of agency, in that actors feel compelled by their roles and the established structure of interaction to continue even once suspicions have been expressed. Because of the kind of face-saving etiquette captured in the proverb c'est "non" qui envoie palabre, at the end of this story everyone maintained their roles and relationships after the events subsided, at least as far as I could document. In this sense deceptive narratives have a tendency to produce a collective social dynamic beyond the control or understanding of the society that hosts them.

\section{ETHNOGRAPHY OF/INSIDE A SCAM}

He came to the airport to meet me, but I almost did not recognize him. Dedy, at the center of my fieldwork in 2001, had been a tautly muscled man always ready to leap physically into an argument between strangers in hopes of making 
some money or at least an ally from the underdog whom he always defended. Now he walked with a limp, his foot paralyzed, and his face looked hollowed out. One of the many times he had succumbed to malaria, he had gone to a clinic to get a shot. The nurse, her first day on the job, stuck the needle into a nerve, paralyzing his foot permanently.

A few days before I arrived, I had also contacted another old friend, Boniface, to ask whether I could stay with him until I found a hotel I felt satisfied with, and he insisted on picking me up at the airport and hosting me during my entire stay. Boniface qualified himself as a "boss," or upper class, while Dedy no longer had a home, but both were among my most trusted friends, people I had relied on during my earlier fieldwork to protect me from being conned, robbed, or otherwise harmed. I could trust either man in a room alone with my wallet, but I had no delusions that either man would refrain from conning me in the right situation. And they would expect nothing else from their closest friends. Dedy had once been robbed of his life savings by his own brother, with whom he nonetheless remained on speaking terms.

Boniface was still living in his parents' old place, but he had converted the courtyard into a tiki-style dining and business area and built an office facing the street, where he had several employees working for him on computers and phones. Before the political crisis, he had made a lot of money servicing transnational oil companies. Fleeing the turmoil, he rebuilt his business in Ghana, where he imported rice from Niger until some Indian business associates ran off with 150 million francs CFA worth of merchandise, ${ }^{4}$ including a convoy of trucks. Now he was starting over with oil in Abidjan again, and he needed to establish new contracts. One day he asked me to do him a favor, which I could not easily refuse given his generosity in hosting me. Without explanation, he asked me to come with him as he drove around town. Soon I found myself walking into a major U.S. oil company's office, where he introduced me as his U.S. supplier to the local manager. I had to field several pragmatic questions with vague responses while trying to mask my inner turmoil over how to handle the situation. Boniface liked to present himself as a successful and legitimate businessman, but he never revealed to me why after twenty years abroad he left his wife and daughter behind in the United States to return to Abidjan penniless.

In 2001, Dedy's way of making a living had involved a wide range of schemes, often involving the pretense that he was an undercover police officer, but in those days his brawn had proven an important factor in his ability to intimidate or fight his way out of a situation. He was a kind of hybrid of two Abidjanais identities, the 
nouchi and the ziguehi. The ziguehi (also referred to in a local twist of a French word as a loubard) was someone who lived by their muscle (Yao 2017). They were avid bodybuilders who used their size and strength to intimidate people. Sometimes they simply demanded money from people using the implicit menace of their mass, and sometimes they offered their protection services. They often worked as security guards outside banks and nightclubs. A nouchi, by contrast, was someone who lived by their wits, always on the hunt for manzements (financial opportunities). A nouchi made money from the margins, one day helping to move some boxes for money, another day snatching a cell phone from a table at a maquis (Ivoirian-style bar), yet another day fencing goods stolen by someone else. Dedy had combined the two strategies, using his power of persuasion in combination with his strength and the threat of violence. Now forced to drag his foot when he walked, Dedy could no longer muster the physical presence that made people fear him.

Frame 1: Wherein the Ethnographer Becomes Witness, Prop, and De Jure Accomplice to a Scam

Dedy had converted himself into a camoracien - local argot for someone who falsifies documents. His specialty was attaining legitimate Ivoirian passports for

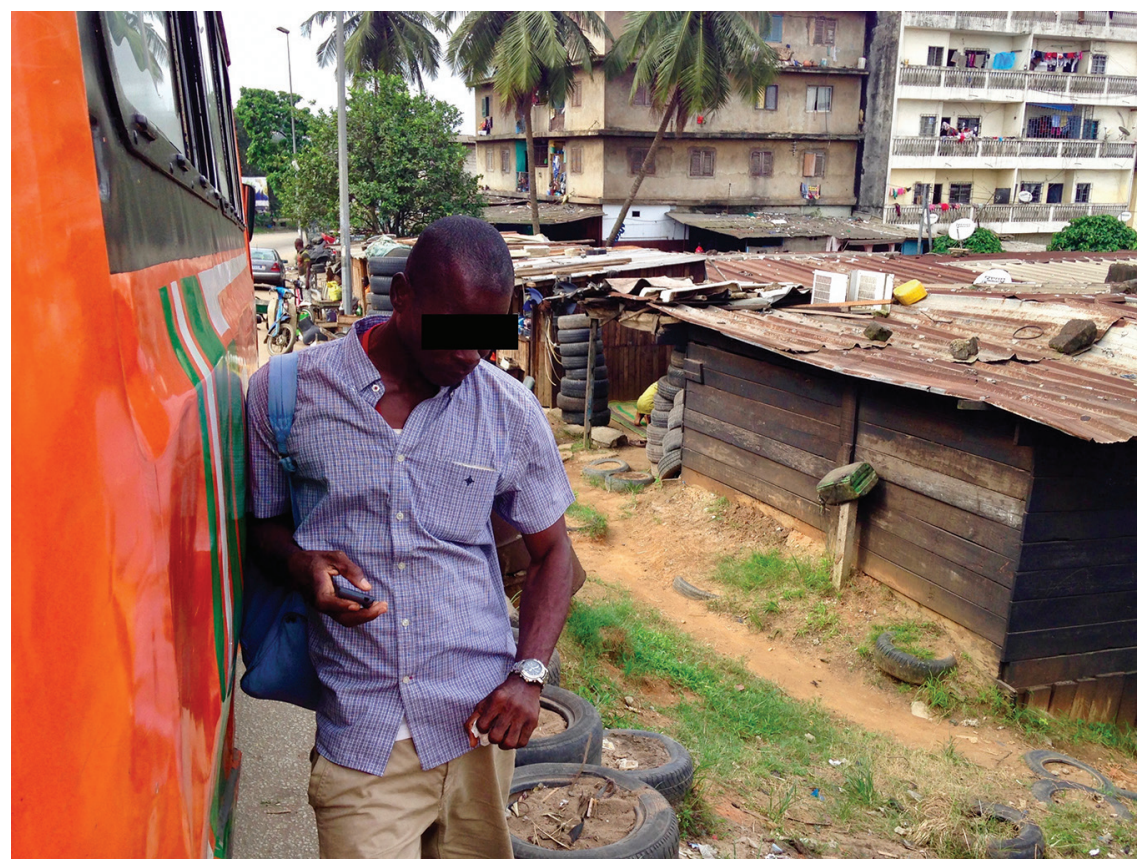

Figure 3. Dedy in action. The watch will figure in the story later on. Photo by Sasha Newell. 
non-Ivoirian residents by falsifying all the paperwork necessary and making use of a contact in a regional state office to obtain copies of genuine forms and certificates and to make sure his faked papers went through proper channels. He admitted this to me right away and introduced me to his Senegalese partner who worked in an internet café, where they were able to make use of his equipment to do the more technical aspects of the forgeries. Dedy explained he had someone waiting to pick up some documents he had promised, and we were behind schedule.

He was in a hurry to leave Treichville because he owed a great deal of money to his old landlord (there was a bounty out in at least two neighborhoods for whoever could find him). Rumors of my presence were sure to circulate, and the heat would only increase when these debtors realized they had a chance at getting paid off now that there was un blanc (a white person) in the equation. Indeed, throughout the following weeks, various parties hunted us in hopes of a payout, offered to leave us alone for a bribe, or suggested themselves as negotiators in hopes of a pourboire (tip). I was happy to pay off enough debt to temporarily satisfy Dedy's pursuers, but I could not help feeling paranoid that this entire scenario was a prearranged scam and that Dedy might be pocketing a portion of the money I was handing over to strangers.

Over the course of that first day in Treichville, as we visited old friends and made amends with his debtors, Dedy received repeated calls from a man listed on the phone only as "Papié [sic] Français" (French Documents), and whom I will refer to as Issa. When the documents were ready, we crossed town by bus to meet Issa on a busy traffic-filled street in Adjame, huddled under an umbrella in the rain. From the way Dedy introduced me, I guessed he had scheduled this meeting just to show he was with un blanc. Indeed, Dedy affirmed later that Issa was much more likely to pay him after seeing me. Dedy handed over the papers he had prepared in Treichville, now sealed in an envelope with an official-looking signature across the seal. That night, while drafting his next official consular document, he explained that Issa and his girlfriend were trying to get French passports by claiming they were siblings born in France. He was helping them to forge documents that would ostensibly make the French embassy believe their names had been changed when they were adopted after their parents had died. Only in fact many of the documents the couple thought were real, like the ones from the French consulate, were also forgeries. Dedy was milking the scam by finding problems that required documents to be refiled, thus accruing more fees. He pointed out proudly that they would never be able to go to the police since they were breaking the law themselves. ${ }^{5}$ Sometimes Dedy believed they might really get the passports in the 
end, like many of his customers seeking Ivoirian citizenship — a tragic irony, given that Dedy himself had tried to get into Europe on a false passport at least twice.

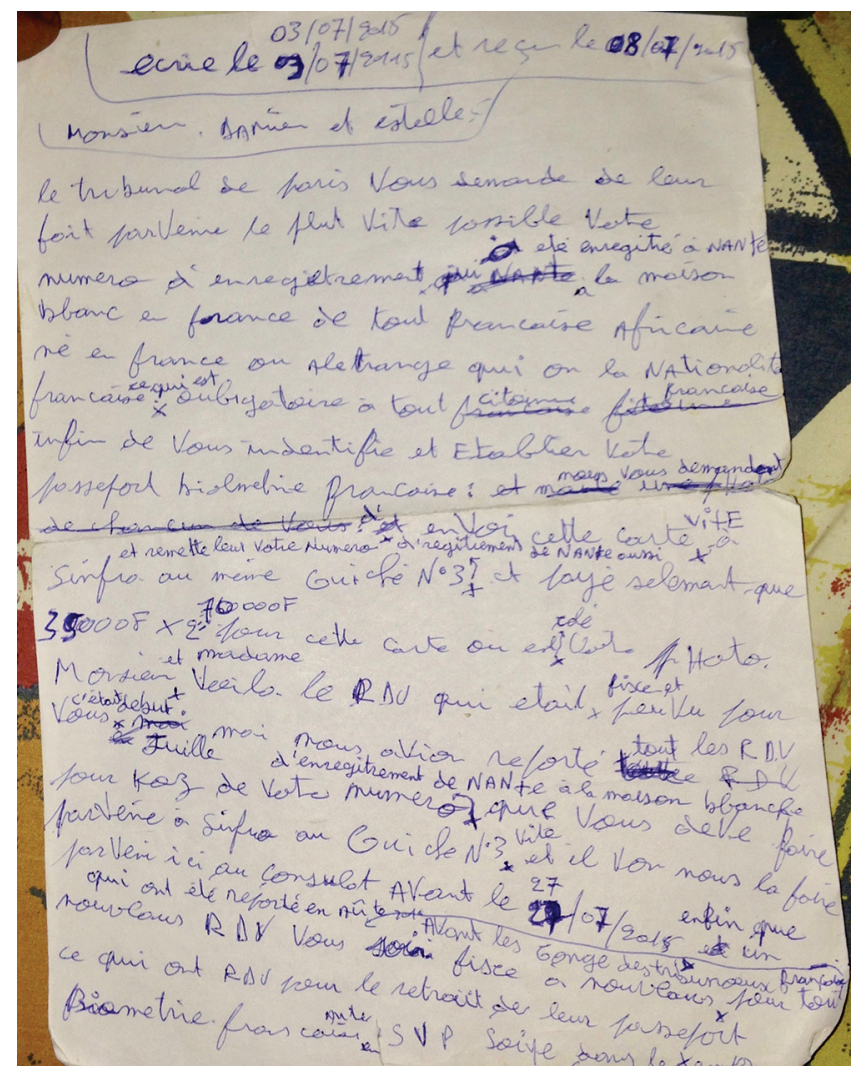

Figure 4. A draft of a counterfeit official letter from the French consulate. Photo by Sasha Newell.

Dedy's current trick was to specify that the form must be completed in black ink, and since the couple had used blue ink, the form required re-filing and, of course, another set of fees. Dedy had several more steps planned, including a registration number that would need to be procured from Nantes, costing around a million francs CFA (about US\$1,700).

Now I found myself in an ethically sticky situation. While I had always known that Dedy made some of his money from illicit operations, I had tried to avoid learning details about them until after the fact. But now not only was I party to an ongoing confidence scheme but I was also clearly being used as a prop to legitimize the scam. Worse still, in any future interaction with Issa I would be complicit if I did not warn him, which would threaten Dedy's sorely needed income and hard work already invested. Yet if I wanted to continue to spend time 
with my old friend, I had little choice but to accept exposure to his way of making a living. Furthermore, this situation constituted an extension and intensification of precisely the kinds of informal economic labor I had studied previously, but to which I seldom had direct access. And perhaps there was ethnographic value in observing this scheme in action, especially considering the relationships it exposed between fake documents and the power of the state (Apter 2005; Bubandt 2009). With no small degree of discomfort, I took notes on the situation and decided to maintain as much distance as possible in the future by refusing to attend any more meetings with Dedy's client.

Frame 2: Wherein Dedy Worries That His Mark May Have Seen through the Ruse, but Decides to Go Ahead Anyway

At the next meeting Dedy left me at a street kiosk. He was expecting to receive a payment of 30,000 francs CFA this time. He came back ten minutes later in great haste and yelled for me to grab a taxi. We were whisked away into the sea of traffic as he related what had happened. When he arrived at the meeting point, he found that Issa had brought his girlfriend, Fatou, whom Dedy had never met. Fatou had become suspicious over the story about the required color of ink, and

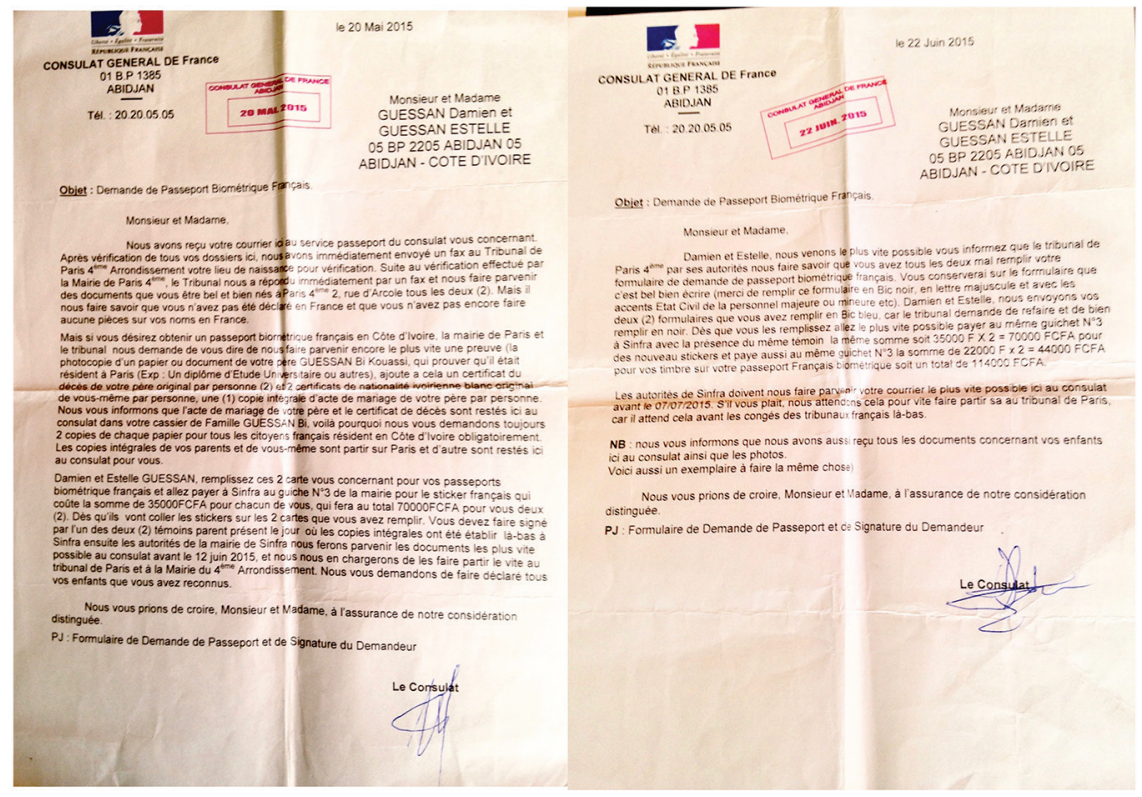

Figure 5. Final forged documents from the French consulate. Notice that there are many errors of French grammar and spelling, but that it was the mismatching signatures that raised Fatou's suspicion of inauthenticity. The names used are aliases. Photo by Sasha Newell. 
now she pointed out several items on the documents that indicated forgery, including mismatched signatures. Issa got up and made a call, standing outside hearing range. Dedy interpreted the situation as dangerous, told them he needed to check on me and was coming right back, and fled. He chastised himself in the car: "I was too rushed [the day you arrived] and I messed up — I should never have included a document with nothing on the back, and the signature was sloppy."

Despite this apparently narrow escape, Dedy was puzzled. He asked, "If they already knew it was a scam, why did they give me back my watch?" In an earlier encounter, Issa had offered to fix the watchband of Dedy's expensive watch given to him by a European. Today he had returned the watch at the beginning of their conversation. Dedy turned the watch over in his hands contemplatively. No, he decided, they must not know he was scamming them, or they would never have given the watch back. That evening Issa and Fatou called to ask why he had disappeared in the middle of their meeting, and they set up a time to meet and finish their bizness, including the payment they owed Dedy. He headed off the next day to the same café in Adjame, while I worked on documenting the infrastructural transformations in Treichville. I was in a clothing shop on Rue 12, the famous Petit Paris, when my cell phone rang.

Frame 3: Wherein Dedy Is Caught and Requires the Ethnographer to Bribe the Police

Disaster had struck. As soon as he sat down at the table with Issa and Fatou, a couple of police officers showed up (one of them Fatou's brother), and they were all promptly escorted to the station in Adjame. Caught red-handed, Dedy had been forced to sign a confession. Since the government was cracking down on forgery because of the international notoriety building around cybercrime, he was at risk of serious prison time. The situation, he was quick to emphasize, could prove lethal given his inability to defend himself with his crippled foot. However, there was some hope - the police officer in charge of his case had taken pity on him. The officer had not entered the case in the records and was willing to set Dedy free; all I needed to do was take a taxi to the police station and return the money Dedy had already siphoned from his victims: 764,000 francs CFA (US\$1,300).

That was a shocking number. If Dedy had received even a portion of that money, why was he homeless and separated from his wife and children because of unpaid debts across town? Furthermore, if I were to pay for his liberty, I would have nothing left of the money I had planned to offer him for his assistance, in 
hopes of giving him a fresh start. I told him I needed to think, and I headed back to Boniface's apartment in Treichville to get a second opinion.

Frame 4: Wherein the Ethnographer Suspects He Is the Actual Mark, and that the Original Scam Was a Ruse Performed to Entrap Him

By the time I arrived, Boniface and his business partner had already received the same call from Dedy and immediately warned me that it was a scam. I was inclined to agree. The police officer would be breaking the law in letting Dedy go, something too risky to do unless he was being paid off — so there seemed little doubt that the couple and the police officer were working together to get what they could out of Dedy's blanc. But it was also possible that Dedy had orchestrated the scheme with the others, that everything that had happened since my first day in Abidjan had been a performance leading to this very moment, when I was expected to pay out to save my friend. "This is what he does for a living," Boniface said, "and he is very good at it. He is exploiting your love for him."

I had the disorienting sensation of reality shifting, or at least of the narrative structure underpinning it, which amounts to much the same. A great portion of the notes I had taken since arriving in Côte d'Ivoire were open to reinterpretation. I had first thought I was merely a friendly bystander to Dedy's professional life, then worried I was being used as a prop to legitimate his con, and finally I became concerned that my knowledge of the true nature of the events made me a complicit participant in their outcome. But now I wondered whether the so-called victims of the scam were in fact participants in a larger confidence game aimed at me. My friend could potentially be imprisoned if I did not show up at the police station, but going could prove a trap — once there, they might claim I was involved in the crime to get more money out of me. I found myself paralyzed and decided at the urging of Boniface to simply wait and see what happened. If it was a scam, he said, we would quickly see a new strategy emerge.

\section{A TURNING: Containment, Re-containment, and Nested Frames}

In considering this moment, I find myself thinking about the notion of turning in a series of Telefolmin initiation rituals in Papua New Guinea. Dan Jorgensen (1990) argues that the men's cult is not made up of a single cosmology but rather a layered set of shifting knowledge schemes. At each phase of initiation to the cult, men are introduced to another piece of the myth that transforms the meaning of everything that came before. The Telefolmin call the act of telling such a secret 
"turning," because it flips what is known on its head. Jorgensen (1990, 41-43) writes:

In a general sense, "turnings" are substitutions amounting to a displacement of conventional meaning . . . the combined effect of such dislocations is to set up a secret world alongside a defamiliarized everyday world. . . . Each secret takes previously established knowledge as its foil, and this is true within the context of the cult as it is outside it. The cumulative effect is to confirm nothing so much as the premise that things are other than what they seem.

The culmination of these turnings occurs when, long after supposedly completing their initiation, men discover that the katibam, which they thought merely a dormitory for old men, was actually another cult house in which the most basic premises of the entire previous series of rituals became overturned, including the moiety system and the distinction between the sexes that organized society as a whole. The most sacred of men's spaces was said to be the one with the women's menstrual house, the most polluted space. This series of revelations "sets up a trajectory whose path sketches the precariousness of the consensual truths by which people live" (Jorgensen 1990, 45), thus teaching Telefolmin men to recognize their own power of social construction in the world, as well as the responsibility to hide it.

My own moment of recognition that my return to Abdijan may have been an orchestrated scam from the beginning was equivalent to a Telefolmin turningthe world was no longer the same, and I began to reinterpret every preceding event according to this new interpretive key. Goffman's (1974) "frame analysis" provides us with some useful language: a frame provides the grounding of meaningful action within it (thus we have ritual frames, frames of intimate sincerity, frames of ceremonial formality, etc.), while a keying marks the transformation of one frame into another, as in Gregory Bateson's $(1972,180)$ famous statement "this is play," where animals perform the same gestures as fighting, but under the guise of knowing from the start they are only playing (see also McGovern 2011). My own involvement going forward, however, took place in the more uncertain realm of "is this play?" (Bateson 1972, 182), and I was never quite sure whether I was in the role of friend, prop, or mark.

Furthermore, Goffman suggests that frames work to contain people so long as their experience coheres with the interpretive frame. When a mark starts to become suspicious, conspirators can offer up a new key to a frame that contains the first, thereby re-containing their escapee. My story seems to involve a series of 
nested deceptions, each one of which, if revealed to those being contained, would represent a turning. The central anthropological question is whether any one person controlled these keyings or whether they were taking place according to the motivations of different actors with different interpretations and motivations.

\section{Interlude of Indeterminacy: Wherein All Actors Attempt to Negotiate the Dominant Narrative Frame}

As Boniface had predicted, the tactics shifted when I did not perform as expected. Within a couple of hours, a cab pulled up at Boniface's door with Dedy and the aggrieved couple. They brought a police document indicating that if Dedy did not return to the police station by the following afternoon with the requested money, he would be arrested immediately. At this point, it seemed very clear that the surface layer or "lamination" (Goffman 1974, 82) was no longer believable, since if the police officer had illegally refrained from entering Dedy in the books, the document for his arrest could not be legitimate either. On the other hand, the performances of grief, loss, betrayal, and Dedy's mournful demeanor at causing me so much stress and financial difficulty seemed convincing. Issa and Fatou tearfully expressed their desire to keep Dedy out of jail, given his friendship with Issa and his physical condition - all they wanted was the rightful reimbursement of the stolen money. I pointed out that they had been actively involved in forging papers themselves, but this did not seem to affect their self-righteous conviction that they were owed compensation.

When at last the couple left amid remonstrations that I show up with the money the next day, Dedy, Boniface, and I were able to sit down and try to work things out. Boniface was angry and accusatory, telling Dedy he should never have dared bring criminals into his home. He derided the police document and telephoned the officer who had signed it to directly accuse him of corruption and grift. The policeman became angry and threatening and hung up the phone. Dedy remained steadfast that he had not schemed with these people but admitted they were probably only demanding money because they knew he walked with un blanc.

Not only was I still uncertain Dedy had plotted against me but I was also unsure how to proceed even if he had. Dedy needed the money more than these people, who by their own admission had paid Dedy to forge their way into Europe illegally and had little moral claim to their illicit investment. The only reason this couple had leverage at all was that 1) I was a potential source of money and 2) a crooked cop with the power to arrest Dedy was hoping to get a portion of that 
for himself. But if I simply refused to show up, or accused them of pulling a scam on me, the officer could still use Dedy's signed confession to send the latter to jail.

\section{Frame 5: Wherein the Ethnographer Proposes to Turn the Scam against His}

\section{Scammers}

What shook Dedy's resolve was when I explained (truthfully) that the money they were asking for amounted to everything I had set aside to give him in compensation for his help. In the middle of that sleepless night, we came up with the plan to pay the supposed victims a token amount of money upfront to satisfy them and promise the rest for after I had already left town. Once I was gone, there would no longer be any way to leverage more money out of the situation. Dedy was not worried about what would happen when I did not show up on the prescribed date: He sneered, "they will never find me" (raising the unasked question - why couldn't he just disappear now?). Dedy called the officer and gave him a concocted story about my wife refusing to wire me the money, so I could only give them a small portion of the requested amount now. At least this way there would be something left over for Dedy when all was done.

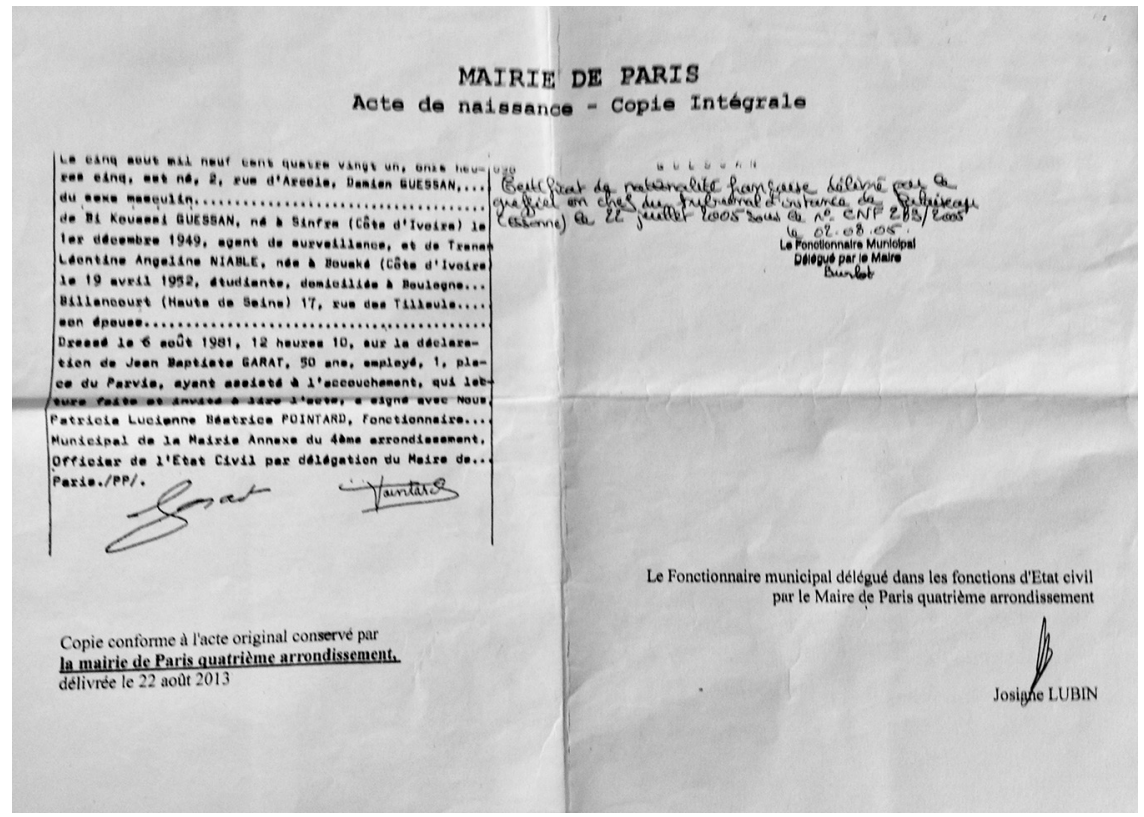

Figure 6. Forged birth certificate from Paris. Photo by Sasha Newell.

However, if Boniface was correct, Dedy might also be getting some portion of the money I was paying to the couple. While this undeniable possibility made 


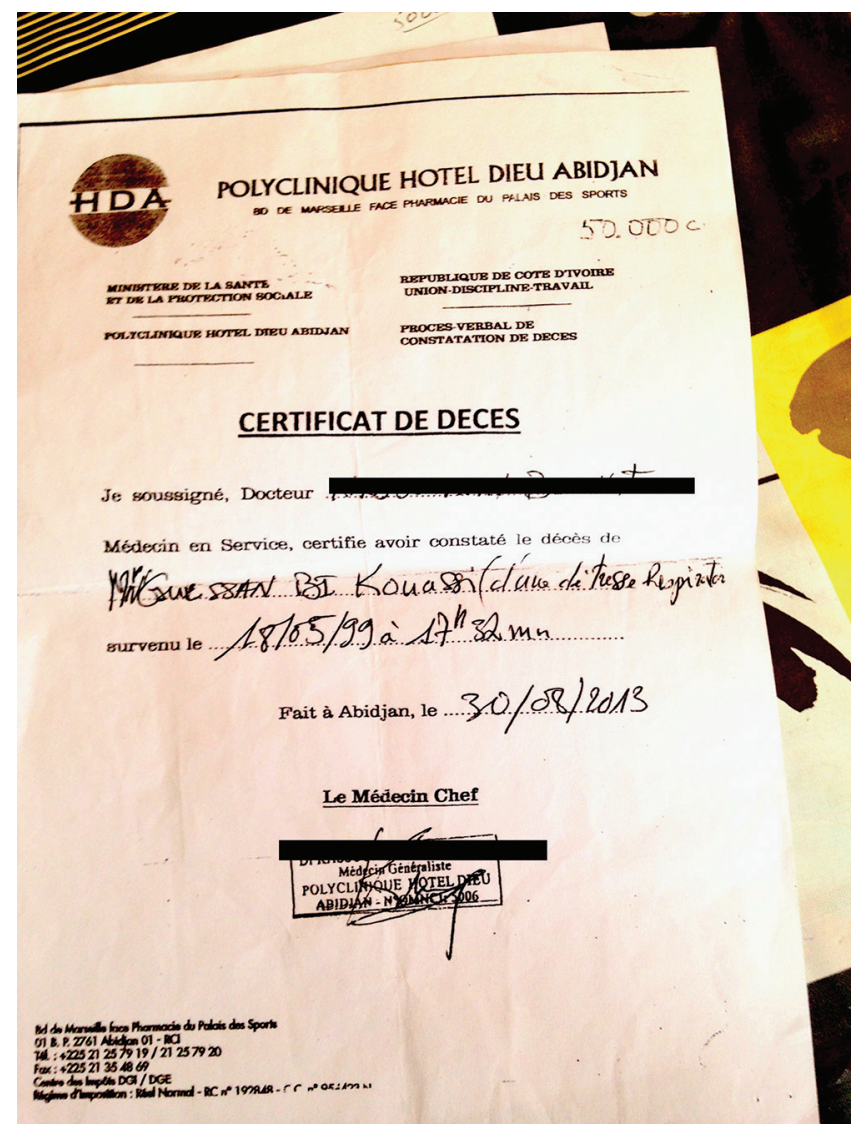

Figure 7. Death certificate of the fictional Ivoirian parent who had died and left them orphans (explaining their subsequent name changes). Photo by Sasha Newell.

me angry, I had long ago reconciled myself to Dedy skimming small amounts of money off me. It was how he lived and formed a part of his interactions with everyone, an understood social modality. Furthermore, I felt implicated in this situation because, whether a fabricated story or not, I had been willing to go on documenting his scam when the going was good. Indeed, some part of me had been delighted when Dedy began to explain to me the ways in which he was making money through document forgery. It was that particular ethnographer's delight of being allowed into the inner circle, the sacred chamber, the backstage-access to the real thing. This same part of me wanted to see the process through, to meet the police officer and watch the situation unfold. So, at this point I fed myself the ego-soothing narrative that whatever happened, it made for good ethnography. I agreed to the plan, so long as I could photograph all the documents that Dedy had passed the couple, along with any documents signed at the meeting with the police 
officer, and as long as this request was passed on and agreed to by all parties in advance. Through this self-constructed fiction of ethnographic authority, I sought to enter the arena with confidence and a sense of control. Thus, I took on the role of my own "cooler," finding new framings to soften the loss of face of discovering one is the dupe (Goffman 1952), a role con artists take when they think the mark will seek the police. Perhaps I was also paying my dues for the fuzzy but nevertheless real benefits I would receive from telling these stories in professional texts later. One might even say that the final narrative frame we are participating in here comprises the encompassing scam drawing the most profit.

Frame 6: Wherein the Ethnographer Nearly Exposes the Officer's Scam to the Chief of Police, but Thinks Better of It

The police officer arrived more than an hour late, and while waiting, we drank a couple of beers with Issa in a stifling, fly-infested bar across from the station, otherwise empty in the mid-afternoon heat. Dedy disappeared, leaving me alone with Issa, suspicion growing over what might be happening behind my back. We talked about Issa's farm and how I ought to come out there sometime in the next few weeks to see it. Remembering the dictum c'est "non" qui envoie palabre, I agreed with pasted-on enthusiasm. When the policeman arrived, oddly and annoyingly jovial, he brusquely waived us all across the street into his office, explaining he was late because it was his day off and he had to find an excuse to get away from his wife. He was in civilian clothes and not supposed to be in the police station, so we had to move quickly. Dedy and Fatou signed papers about the payment agreement, delineating when the rest of the money would be paid back. As I was counting out cash for the down payment, the chief of police walked in and the officer's face crumbled. The chief asked why he was in the office that day, scanning the room with suspicion, in response to which the officer lamely claimed to be taking care of unfinished work. For a panicked moment, I saw the opportunity to expose the entire operation, and envisioned the tantalizing possibility of the officer getting arrested. But in addition to the risk of prison for Dedy, it felt impossible to breach the social roles we were falsely playing. I remained silent, helplessly watching the chief leave the room, obviously aware that something improper was going on but deciding to let it go. Perhaps he too would demand his cut of the proceeds later on - that, at any rate, was Dedy's theory. Dedy and I left the others shortly afterward, everyone shaking hands with everyone, the others hanging back, perhaps to split up the money. 


\section{INCONCLUSION}

There is no definitive conclusion to this story, ${ }^{6}$ no moment in which I could say with certainty that I knew what had actually happened, and this ethnographic indeterminacy is perhaps the most important point-I believe that none of those involved held the complete story. Social reality is made collectively visible through narrations that are constant objects of contestation (Bakhtin 1981). Much as no speaker (or author) controls language or even the very words they employ, so that interpretation is always a contested pushmi-pullyu of forces between parties concerned. ${ }^{7}$ Knowledge of what actually happened is not owned by any of the actors involved, even as the possibility of controlling the narrative frame has financial repercussions for all parties concerned. Instead, contesting narrative layers pile on one another in ways that leave only portions visible from any given perspective, allowing for new narrative interpretations and future profits. Opacity can allow for an open-endedness potentially socially productive for everyone, in part because everyone can save face (Strathern 2000; Archambault 2017).

Dedy's version of events - that he was only trying to scam the "papiers français" people and I simply happened to be in town to rescue him when things went bad-remains plausible, but unconvincing. I watched him carefully in the following weeks for some slipup or admission to his part in the scam, but no clear evidence or confession emerged. Boniface's version is also possible; Dedy may have colluded with these people from the beginning to get what they could out of me. But when I look at the numerous detailed forgeries produced as part of the scam (of which I have only revealed a small selection), I cannot accept that they were produced solely for my benefit, especially when there was no certainty I would even ask to see them.

The most likely scenario is one of continuous improvisation that left everyone involved struggling to remain in control of the narrative frame. Fatou and Issa had wanted to deceive border control by claiming false identities but were deceived in turn by Dedy who was using their dream to extract hard-earned farm money from them with fee after Kafkaesque fee. Suspicions raised, they in turn lured Dedy into a trap using Fatou's familial connection to the police. But, once caught, Dedy may have turned the situation to his advantage by making me (and Boniface) targets of the group's avarice as possible sources of income. No one profited from Dedy going to jail, but keeping him out of jail might bring them all some cash, given that he had un blanc. When Dedy and I conspired to contain his captors and/or co-conspirators, fooling them into thinking they would collect the full sum at a later date, they may have been pretending to believe us, considering partial 
payment better than none, or Dedy may have agreed to pay them some of what I passed to him later. Crucially, apart from the possibility that I was contained the entire time by a frame I never became aware of, no single actor controlled the framing process throughout the series of events.

Jan Beek's (2016) remarkable ethnography of the Ghanaian police interaction with scammers provides a parallel example of how role play continues to structure a situation whose narrative frame is no longer certain. The police have found that the only reliable way to catch scammers is to use the techniques of scammers, concocting elaborate narratives through which they trap them into meeting face to face where they can be arrested. Still, the police are likely to find themselves pawns in struggles between scammers, who use the police to get back at former colleagues who betrayed them, thereby containing the police fabrications. Beek $(2016,311)$ found himself in the remarkable situation of playing a fictional role in a police-fabricated scam to trap scammers:

Just before our next scheduled meeting, the scammer called me but quickly gave the phone to his partner, whom he introduced as a German colleague. The man on the other line spoke perfect German, slightly vernacular. He introduced himself as being from Mainz in Germany and we did some small talk. After some sentences I realized that I had met this man several weeks earlier in another CID office. He was a sixty-year-old, grandfatherly man and had been introduced to me as a German fraud victim from Frankfurt and we had talked a bit. Now, I understood that this man was collaborating with the scammers, knew of the police involvement and probably had learned my real name. Remarkably, neither he nor I said anything about this in our phone conversation; instead, we played along with the fictions concocted by Mr. Benson and Detective Kofi.

Despite all parties probably being aware that they were playing a purposeless charade, no one chose to break frame and discuss what was going on. Everyone continued to play their part until the end of the performance, just as we all did in the policeman's office in my own story. And although my relationship with Dedy had now become tainted with suspicion, something he knew and clearly felt hurt by, we continued on for the next few weeks largely as if nothing had happened — sharing meals and hotel rooms, and traveling to visit his wife-because this was the best we could both make of the situation. 
This kind of uncertainty mixed with intimacy was not unique to my position as an outsider; it proliferated within everyday activity in Abidjan, and I suggest this kind of epistemic anxiety (Ashforth 2005) over how to judge the sincerity of others constituted a recognized aspect of the fabric of daily life. As I had been warned early on, in Abidjan friends and lovers made for the most dangerous kind of contacts. It is impossible to have genuine relationships of intimacy without some degree of trust, and trust was an opening, a vulnerability that could easily be exploited; it often was. Friends sometimes stole from friends, who rarely called them on it if they valued the relationship. Lovers made demands on one another that could damage economic well-being. And then there was the channel of gossip, through which intimates could provide privileged access to information that others could exploit, preserving the relationship while profiting from it at the same time. I would not want to imply that every relationship was run through with such betrayals, but I do believe it was wise for people to remain suspicious, not only in their negotiations with strangers and acquaintances but also with their most trusted associates, who might, out of necessity, take advantage of that trust.

Witchcraft, as Peter Geschiere (2013) writes, constitutes the dark side of kinship. In this region, the classical locale of witchcraft is in the intimacy of the home- by some accounts witches can only bewitch their own blood kin, though new urban forms have emerged that can affect strangers (Bonhomme 2012). Geschiere's phrase is not only intended to highlight the ability of witchcraft to penetrate the most intimate of belongings; it also seeks to challenge the anthropological bias of considering familial intimacy a space of security and shared wealth. As such we might consider West African cosmologies of witchcraft to be a version of the opacity-of-minds philosophy of Melanesianist literature. Ivoirians and others who subscribe to this cosmology of witchcraft exhibit a profound distrust of their ability to read others, even those with whom they have the most shared history and the most invested trust.

However, unlike in accounts of Melanesian societies, in Abidjan the ability to second-guess such opacity and interpret signs of hidden malevolence represents a treasured skill and necessary survival strategy, something highlighted by the Ivoirian slang term yere, meaning both "to scam" and to "see clearly" (Newell 2012, 11). Indeed, grounds exist for a wider regional discussion of this semiotic ideology of opacity in relation to techniques for clarification. For example, Katrien Pype (2017, 98) describes the Lingala term mayele, which includes meanings such as “1. Knowledge, intelligence, malice, prudence, wisdom 2. Artifice, astuteness, deception, bad intention, intrigue, ruse, trick 3. Manner, way, tactic, tact 4. Spirit, 
mentality," and she intriguingly links it not only to new "smart" technologies but also to scams, political promises, artistic production, and mystical occult techniques. Similarly, Birgit Meyer (2003, 27) has described the "spirit of discernment" whereby Pentecostal churches, through confession, spiritual revelation, and video representation, manage to make the darkest and innermost interiors visible to their congregations. This yearning for new techniques of discernment indicates just how fraught the need to play along with pretense can be in the face of indeterminacy.

Though beyond the reach of this article, it would be interesting to investigate the regional variations of the corporealization of interiority in relation to semiotic ideologies of transparency, opacity, and discernment. There is evidence that hearts (see Devisch 1990; Pype 2015; Monteith 2018) may be a more common metaphor for inner motivation than mind, and even in Melanesia, Rupert Stasch (2008, 444) tells us that the Korowai "identify cognitive and emotional deliberation with spaces of bodily interiority, specifically the internal cavity of a person's torso, and the organs." African bellies are also often the vehicle through which witchcraft overcomes a person's self-control after they are tricked into eating human flesh or accepting sexual relations with a witch, either form of bodily invasion causing them to lose control of their interior volition (Geschiere 1997; De Boeck and Plissart 2004).

Witchcraft cosmologies lend themselves to thinking about competing discursive positions of containment and re-containment, as in Harry G. West's (2007) superb comparison of ethnography and sorcery, wherein sorcerers see their victims from the invisible second world while being seen by countersorcerers who remain invisible to witches. Yet it remained a matter of rumor who was who:

In the sorcery-filled Muedan lifeworld we shared, every maneuver was the starting point for countermaneuver, every spin the stuff of counterspin, every interpretative vision the object of subsequent (re)visionings. Accordingly, any Muedans who "recognized" the power inherent in the ethnographer's transcendent vision implicitly asserted that they had managed to fix the anthropological seer in their own sights and thus to transcend his view. (West 2007, 84)

Stasch's (2008) masterful argument concerning the Korowai refusal to discuss others' minds focuses on authority. He demonstrates not only that actors often do not feel they have the right to speak about the motivations of others but also that they 
question their expertise concerning their own. This insight helps demonstrate the complexity of attaining the kind of sincerity espoused by Webb Keane's (2002) converts to Protestant modernity, in which interiority and exteriority match perfectly, especially when cosmologies explicitly allow for multiple agents to gain control of a person's body.

Thus Abidjan's sociality of scamming helps us see a world in which everyday interactions compose interminable struggles of containment and re-containment within even the most intimate of social spheres - the struggle existing over the very definition of a shared world. The result is a story without resolution, in which protagonists and victims remain difficult to sort out for actors and observers alike. By capturing this more explicit sense of everyday opacity in social interactions I want to challenge North Atlantic fixations on sincerity, transparency, and authentic mutual intimacy as achievable or even desirable states of human affairs (Shils 1956; Habermas 1991; Keane 2002). Collectivities based on transparent consensus are fictions through which we enable the continuation of everyday life, because c'est "non" qui envoie palabre. Sociality is built on precisely the layerings of pretense I have described in the confidence games above, frames upon frames. Not only do we pretend but (especially when our social authority is insecure) we also pretend not to see through the pretense, because breaking the frame produces unpredictability, confusion, and the potential for humiliation.

Keane (2008, 479), building on Stasch's (2008) argument about authority and opacity, argues that rather than actually not knowing the minds of others, Melanesians politely pretend that others around them are impenetrable - an unknowing knowing. The situation in Abidjan is the reverse - a knowing unknowing. Actors are all too aware that every act may have hidden and malevolent intentions, but, knowing that they do not know, they pretend that they do, dissimulating trustfulness and camaraderie. This situation in fact resembles one that all ethnographers find themselves in: wanting nothing more than to be included in their group enough to engage in authentic participation, the most common experience is a polite façade of face-saving inclusion, combined with daily practices of dissimulated microexclusions. At the same time, the ethnographer often attempts to perform as though they are one of the group, all the while maintaining an internal distance that allows for an observation and interpretation of the proceedings.

A common greeting in Abidjan is on est ensemble (we are together), combined with the gesture of a fist bumping against one's own chest. It serves as an assertion of empathy and shared motivations. Curiously, however, the expression exploits the Francophone propensity to place the action in the third person, making the 
literal translation more abstract and puzzling: "one is together." Something like the Zen koan about one hand clapping, the phrasing suggests that in the abstract, an unspecified third person who stands for everyone is "together," but refrains from directly including any of the people present in that imagined collectivity. Spelled out this way, it would seem to indicate the desire to be together, ideally, if trust could be established, and the possibility that this is already happening, hopefully. This is really the most the ethnographer can hope for, so far as empathetic understanding goes: somebody is together, and there is the always deferred possibility that that somebody might include us.

\begin{abstract}
This essay considers ethnography in a social world rife with quotidian duplicity, where the pretense of ongoing sociality must continue even when betrayers have been unmasked and deceptions unraveled. The article follows my unintentional entanglement in a series of confidence schemes in Abidjan to explore the ways in which such scams develop their own agentive force beyond the control of their participants. Driven by the performative efficacy of its own narrative and role-play structure, the frame of duplicity sometimes exceeds the control of its authors. My own participation involved a spectrum of roles progressing from 1) innocent passerby, 2) an unwitting set piece meant to convey legitimacy, 3) an ethically compromised ethnographer, and 4) the target of the scam, all the way through to 5) an active participant in deceptionwith several of the roles converging at times. Ethnography inside a scam allows for reflection into the role of deception in everyday social interaction, as well as within the engagements of fieldwork itself. [deception; scams; urban Africa; sincerity; ethnography; Ivory Coast]
\end{abstract}

\title{
RÉSUMÉ
}

Cet essai considère les enjeux d'ethnographie dans un monde social truffé de duplicité quotidienne, où la performance des relations sociales doit continuer même lorsque les menteurs ont été démasquées et les tromperies révélées au grand jour. Mon article revient sur mon engagement involontaire dans une succession d'arnaques à Abidjan afin d'explorer les manières dont de telles escroqueries développent leur selon les logiques qui leur sont propres, échappent parfois même au contrôle de ceux qui les ont mises en place. Ma propre position a impliqué un éventail de rôles qui mont fait passer de 1) un témoin accidentel, 2) la pièce innocente d'un mécanisme destiné à inspirer confiance, puis à 3) un ethnographe compromis sur le plan éthique, et à 4) la cible de l'arnaque et 5) un participant actif à l'affaire. Ces différents rôles se sont parfois entremêlés. Faire de l'ethnographie de l'intérieur d'une telle arnaque permet de réfléchir au rôle de la duplicité dans les interactions quotidiennes, comme dans le travail de terrain. [duplicité; escroqueries; Afrique urbaine; sincérité; ethnographie; Côte d'Ivoire] 


\section{NOTES}

Acknowledgments This research for this article was funded by the Wenner-Gren Foundation and North Carolina State University. An earlier version was presented at a 2017 workshop sponsored by the Wenner-Gren Foundation, the European Association of Social Anthropologists, the University of Manchester, and HAU/The Society for Ethnographic Theory.

1. It turns out that Clifford Geertz's $(1973,27)$ version, as he implies himself ("there is an Indian story - at least I heard it as an Indian story...”), is just one among many, which include many purported originators, including William James and Bertrand Russell, and where the protagonist is as often an old woman as an Indian guru. This is one of those occasions where Wikipedia, being itself turtles all the way down, proves the most authoritative source; see https://en.wikipedia.org/wiki/Turtles_all_the_way_down.

2. This paragraph describes a phenomenon widespread throughout West Africa (and beyond), in which a moral imperative exists to say yes out of politeness regardless of one's actual intentions. However, this practice was arguably exacerbated by the density of urban entanglements, making it simultaneously more frustrating and more necessary for all parties.

3. This is a staple of the confidence scheme film genre: see, for example, 9 Queens, The Grifters, The Spanish Prisoner, and Matchstick Men.

4. At the time, 150 million francs CFA was close to US\$300,000.

5. This is a classic element of cons. By involving the mark in ethically questionable or illegal behavior, the con artists insulate themselves from public complaints once the victim discovers they have been had (Goffman 1952).

6. I (Newell 2006) once teased Lambek (1993, 406) for ending his ethnography with the words "in conclusion, inconclusion." I now find myself indebted to his cleverness. Conclusion, though as necessary and desirable as ever, must always be provisional. Anything more is the opacity of self-deception.

7. The pushmi-pullyu is a fictional animal discovered by Dr. Dolittle on his adventures (Lofting 1920). The animal has two heads, one on each end of its body.

\section{REFERENCES}

Apter, Andrew

2005 The Pan-African Nation: Oil and the Spectacle of Culture in Nigeria. Chicago: University of Chicago Press.

Archambault, Julie Soleil

2017 Mobile Secrets: Youth, Intimacy and the Politics of Pretense in Mozambique. Chicago: University of Chicago Press.

Ashforth, Adam

2005 Witchcraft, Violence, and Democracy in South Africa. Chicago: University of Chicago Press.

Bakhtin, Mikhail M.

1981 The Dialogic Imagination: Four Essays. Edited by Michael Holquist. Translated by Caryl Emerson and Michael Holquist. Austin: University of Texas Press.

Bateson, Gregory

Beek, Jan

1972 Steps to an Ecology of Mind. Chicago: University of Chicago Press.

2016 "Cybercrime, Police Work and Storytelling in West Africa." Africa 86, no. 2: 30523. https://doi.org/10.1017/S0001972016000061.

Bonhomme, Julien

2012 "The Dangers of Anonymity: Witchcraft, Rumor, and Modernity in Africa." HAU 2, no. 2: 205-233. https://doi.org/10.14318/hau2.2.012. 
Bubandt, Nils

2009 "From the Enemy's Point of View: Violence, Empathy, and the Ethnography of Fakes." Cultural Anthropology 24, no. 3: 553-88. https://doi.org/10.1111/j.15481360.2009.01040.x.

Comaroff, Jean, and John L. Comaroff, eds.

2001 Millennial Capitalism and the Culture of Neoliberalism. Durham, N.C.: Duke University Press.

Cutolo, Armando, and Richard Banégas

2012 "Gouverner par la parole: Parlements de la rue, pratiques oratoires et subjectivation politique en Côte d'Ivoire.” Politique Africaine 127, no. 3: 21-48. https://doi. org/10.3917/polaf.127.0021.

De Boeck, Filip, and Marie-Françoise Plissart

2004 Kinshasa: Tales of the Invisible City. Ghent: Ludion.

Devisch, Rene

1990 "The Human Body as a Vehicle for Emotions among the Yaka of Zaire." In Personhood and Agency: The Experience of Self and Other in African Cultures, edited by

Geertz, Clifford Michael Jackson and Ivan Karp, 115-33. Stockholm: Almqvist and Wiksell.

1973 “Thick Description: Towards an Interpretive Theory of Culture." In The Interpretation of Cultures, 3-32. New York: Basic Books.

Geschiere, Peter

1997 The Modernity of Witchcraft: Politics and the Occult in Postcolonial Africa. Translated by Janet Roitman and Peter Geschiere. Charlottesville: University of Virginia Press.

2013 Witchcraft, Intimacy, and Trust: Africa in Comparison. Chicago: University of Chicago Press.

Goffman, Erving

1952 "On Cooling the Mark Out: Some Aspects of Adaptation to Failure." Psychiatry 15, no. 4: 451-63. https://doi.org/10.1080/00332747.1952.11022896.

1974 Frame Analysis: An Essay on the Organization of Experience. New York: Harper and Row.

Guyer, Jane, with LaRay Denzer

2009 "The Craving for Intelligibility: Speech and Silence on the Economy under Structural Adjustment and Military Rule in Nigeria." In Economic Persuasions, edited by Stephen Gudeman, 97-117. New York: Berghahn.

Habermas, Jürgen

1991 The Structural Transformation of the Public Sphere: An Inquiry into a Category of Bourgeois Society. Translated by Thomas Burger with the assistance of Frederick Hultin, Niklas Lawrence. Cambridge, Mass.: MIT Press. Originally published in 1962.

2013 “Law, Opacity, and Information in Urban Gambia." Social Analysis 57, no. 3: 42-57. https://doi.org/10.3167/sa.2013.570303.

Jorgensen, Dan

1990 “Secrecy's Turns." Canberra Anthropology 13, no. 1: 40-47. https://doi.org/10. 1080/03149099009508488.

Keane, Webb

2002 "Sincerity, 'Modernity,' and the Protestants." Cultural Anthropology 17, no. 1: 6592. https://doi.org/10.1525/can.2002.17.1.65.

2007 Christian Moderns: Freedom and Fetish in the Mission Encounter. Berkeley: University of California Press.

2008 "Others, Other Minds, and Others' Theories of Other Minds: An Afterword on the Psychology and Politics of Opacity Claims." Anthropological Quarterly 81, no. 2: 473-82. https://doi.org/10.1353/anq.0.0000. 
Lambek, Michael

1993 Knowledge and Practice in Mayotte: Local Discourses of Islam, Sorcery, and Spirit Possession. Toronto: University of Toronto Press.

Lofting, Hugh

1920 The Story of Doctor Dolittle. New York: Frederick A. Stokes Company.

Maurer, David M.

1940 “The Argot of Confidence Men." American Speech 15, no. 2: 113-23. https://doi.

McGovern, Mike org/10.2307/486816.

2011 Making War in Côte d'Ivoire. Chicago: University of Chicago Press.

Meyer, Birgit

2003 "Visions of Blood, Sex and Money: Fantasy Spaces in Popular Ghanaian Cinema." Visual Anthropology 16,no.1:15-41.https://doi.org/10.1080/08949460309595097.

Monteith, William

2018 'Showing 'Heart' while Making Money: Negotiating Proximity in a Ugandan Marketplace." Africa 88, S1: S12-30. https://doi.org/10.1017/S0001972017001127.

Newell, Sasha

2006 "Estranged Belongings: A Moral Economy of Theft in Abidjan, Côte d'Ivoire." Anthropological Theory 6, no. 2: 179-203. https://doi.org/10.1177/ 1463499606065034.

2009 "Godrap Girls, Draou Boys, and the Sexual Economy of the Bluff in Abidjan, Côte d'Ivoire." Ethnos 74, no. 3: 379-402. https://doi.org/10.1080/00141840903053139.

2012 The Modernity Bluff: Crime, Consumption, and Citizenship in Côte d'Ivoire. Chicago: University of Chicago Press.

Pype, Katrien

2015 "The Heart of Man: Pentecostal Emotive Style in and beyond Kinshasa's Media World." In New Media and Religious Transformations in Africa, edited by Rosalind I. J. Hackett and Benjamin F. Soares, 116-36. Bloomington: Indiana University Press.

2017 "Smartness from Below: Variations on Technology and Creativity in Contemporary Kinshasa." In What Do Science, Technology, and Innovation Mean from Africa? edited by Clapperton Chakanetsa Mavhunga, 97-116. Cambridge, Mass.: MIT Press.

Robbins, Joel, and Alan Rumsey

2008 "Introduction: Cultural and Linguistic Anthropology and the Opacity of Other Minds.” Anthropological Quarterly 81, no. 2: 407-420. https://doi.org/10.1353/

Roitman, Janet anq.0.0005.

2004 Fiscal Disobedience: An Anthropology of Economic Regulation in Central Africa. Princeton, N.J.: Princeton University Press.

Shils, Edward A.

1956 The Torment of Secrecy: The Background and Consequences of American Security Policies. New York: The Free Press.

Smith, Daniel Jordan

2008 A Culture of Corruption: Everyday Deception and Popular Discontent in Nigeria. Princeton, N.J.: Princeton University Press.

Stasch, Rupert

2008 "Knowing Minds Is a Matter of Authority: Political Dimensions of Opacity Statements in Korowai Moral Psychology." Anthropological Quarterly 81, no. 2: 443-58. https://doi.org/10.1353/anq.0.0009.

Strathern, Marilyn

2000 "The Tyranny of Transparency." British Educational Research Journal 26, no. 3: 309-

West, Harry G. 21. https://doi.org/10.1080/713651562.

2007 Ethnographic Sorcery. Chicago: University of Chicago Press. 


\section{Yao, Séverin Kouamé}

2017 "Nouchis, ziguéhis et microbes d'Abidjan: Déclassement et distinction sociale par la violence de rue en Côte d'Ivoire." Politique Africaine 148, no. 4: 89-107. https:// doi.org/10.3917/polaf.148.0089. 